\title{
Prevotella in Pigs: The Positive and Negative Associations with Production and Health
}

\author{
Samat Amat ${ }^{1,2}$, Hannah Lantz ${ }^{1}$, Peris M. Munyaka ${ }^{1}$ (D) and Benjamin P. Willing ${ }^{1, *}$ \\ 1 Department of Agricultural, Food and Nutritional Science, University of Alberta, \\ Edmonton, AB T6G 2P5, Canada; samat.amat@ndsu.edu (S.A.); lantz@ualberta.ca (H.L.); \\ munyakam@ualberta.ca (P.M.M.) \\ 2 Department of Microbiological Sciences, North Dakota State University, Fargo, ND 58108-6050, USA \\ * Correspondence: willing@ualberta.ca; Tel.: +1-780-492-8908
}

Received: 1 September 2020; Accepted: 11 October 2020; Published: 14 October 2020

\begin{abstract}
A diverse and dynamic microbial community (known as microbiota) resides within the pig gastrointestinal tract (GIT). The microbiota contributes to host health and performance by mediating nutrient metabolism, stimulating the immune system, and providing colonization resistance against pathogens. Manipulation of gut microbiota to enhance growth performance and disease resilience in pigs has recently become an active area of research in an era defined by increasing scrutiny of antimicrobial use in swine production. In order to develop microbiota-targeted strategies, or to identify potential next-generation probiotic strains originating from the endogenous members of GIT microbiota in pigs, it is necessary to understand the role of key commensal members in host health. Many, though not all, correlative studies have associated members of the genus Prevotella with positive outcomes in pig production, including growth performance and immune response; therefore, a comprehensive review of the genus in the context of pig production is needed. In the present review, we summarize the current state of knowledge about the genus Prevotella in the intestinal microbial community of pigs, including relevant information from other animal species that provide mechanistic insights, and identify gaps in knowledge that must be addressed before development of Prevotella species as next-generation probiotics can be supported.
\end{abstract}

Keywords: animal production and health; gut microbial ecology; immune system; microbiota; Prevotella; pig

\section{Introduction}

A diverse and dynamic microbial community (known as microbiota) resides within the pig gastrointestinal tract (GIT) and contributes to host health and performance by mediating nutrient metabolism, modulating the immune system, and providing colonization resistance against pathogens [1-3]. These beneficial traits of the gut microbiota are influenced by host condition, dietary, environmental and management factors. Perturbation of well-balanced (homeostatic) microbial populations is known to have long-term adverse effects on host physiology [4-7]. For example, antibiotic perturbation of the piglet GIT microbiota in early life has been shown to be associated with impaired gut microbiome development and altered metabolic regulation later in life [8]. Furthermore, compromised resistance against infectious agents has been reported in pigs raised under more hygienic and controlled conditions [9]. Pigs that develop post-weaning diarrhea have also been observed to have distinct early-life microbiota profiles [10]. Restoration of the gut microbiota homeostasis in pigs has become an active area of research in order to enhance animal health and production through different strategies. For example, fecal microbiota transplantation (FMT) is one of the strategies used to improve pig health through modulation of the gut microbiota [11-13]. Understanding the biology and role of key members of the pig gut microbial community in defining host physiology is necessary to 
deduce the complex guiding principles that govern microbiota-host interactions in the gut, which will ultimately facilitate the development of gut microbiota-targeted strategies to improve pig health and productivity.

Prevotella is one of the most predominant genera across the large intestine of pigs $[14,15]$. This genus is also a central constituent in one of the two most common bacterial enterotypes of gut microbiota in pigs, especially after weaning (Prevotella vs. Treponema-dominant enterotypes, Prevotella vs. Ruminococcaceae enterotypes) [16-19]. The Prevotella-driven enterotype has shown positive associations with animal traits including feed intake [18], feed efficiency [17], weight gain [19] and incidence of diarrhea [10], suggesting that Prevotella is important in mediating growth performance and disease resilience in pigs. Moreover, network analysis revealed that Prevotella is a highly connected taxa that exhibits strong competitive and cooperative interactions with many members of gut microbiota [12,17]. Considering the new definition of keystone taxa [20], Prevotella can be considered as a keystone taxon, as it has a profound influence on community structure and function of the gut microbiota in pigs.

Prevotella spp. are not only key members of the intestinal microbiota in pigs, but are commonly present in many different mammalian species including humans [21], non-human primates [22], mice [23], ruminants [24] and poultry [25]. Being one of the most predominant genera among the rumen microbiota, Prevotella spp. contributes significantly to both carbohydrate and nitrogen metabolism in ruminants [26-28]. Human gut Prevotella has received considerable attention due to its associations with host diet and metabolism [21,29], immune response [30], and mental health [31]. The role of Prevotella in defining human health, however, still remains controversial [32]. Many studies have employed rodent models to study Prevotella in humans [33-35], however, given the high degree of similarity in anatomy, physiology and immunology between pigs and humans, pig models may be more clinically relevant to humans than rodent models [36-38]. Therefore, providing a cohesive summary of the findings on gut Prevotella from the studies conducted in pigs may also enhance our understanding of the role of Prevotella in human health. The overall goal of this review is to summarize the current knowledge of Prevotella in the pig gut and its associations with microbiome-mediated growth performance and host health. In addition, some challenges associated with characterization of Prevotella in the pig gut, and future research directions to overcome these challenges will be discussed.

\section{Microbial Ecology along the Pig Gastrointestinal Tract}

\subsection{Microbial Composition and Diversity}

The pig GIT harbors diverse and dynamic microbial ecosystems consisting of bacteria, archaea, fungi and viruses [39]. Bacteria with cell densities ranging from $10^{10}-10^{12}$ cells per gram colon contents and feces [40] comprise most of the GIT microbiota. According to a recent meta-analysis, the bacterial microbiota of pig GIT encompasses up to 35 different bacterial phyla, 880 genera, and 25,000 operational taxonomic units (OTUs) [14]. Prevotella spp. are present throughout the GIT and their abundance, physiological role within the gut, and influence on the host phenotype are constantly influenced by the interaction network structure existing amongst the gut microbial community [12,17]. Thus, to understand the role of Prevotella in modulating host phenotype, here, we briefly review the bacterial microbiota present within the pig GIT.

Discrete bacterial communities are present in the different microhabitats along the GIT, with bacterial density, community diversity and evenness increasing from the proximal to distal GIT $[14,41,42]$. Similar to the pattern where bacterial distribution differs by the longitudinal axis (proximal to distal), bacterial community structure and diversity also differ from lumen to mucosa [15]. As such, the mucosal bacterial community has been found to be significantly richer than that of the lumen in both the ileum and the cecum $[14,15]$.

Firmicutes, Bacteroidetes and Proteobacteria are the most predominant phyla found in the GIT $[12,41,43]$. Firmicutes remains as the most predominant phylum in both upper and lower GIT [44]. The second most abundant phylum in the upper GIT is Proteobacteria; however, its abundance 
decreases in the lower GIT where strict anaerobic Bacteroidetes substitutes it [14,15]. Most of the core genera identified within the swine GIT are Clostridium, Blautia, Lactobacillus, Prevotella, Ruminococcus, and Roseburia, RC9 gut group, and Subdoligranulum [14,15].

\subsection{Factors Shaping the Bacterial Microbiota in the Pig Gastrointestinal Tract}

Different physiological conditions along the GIT account for discrete microbial community structure and composition (Figure 1). The $\mathrm{pH}$ in the stomach is significantly lower than the rest of the GIT; thus, the more acid-tolerant bacteria species such as Lactobacillus are more abundant [45]. Another physiological factor that may influence the microbial distribution along the GIT is bile [46]. Since bile has detergent and antimicrobial properties, the presence of bile acids in the small intestine favors bacteria that are bile tolerant [46-48]. In addition, bacterial colonization in the GIT is also influenced by the mucus layer covering the intestinal epithelium. The mucus layer serves as a physical barrier to keep pathobionts in the GI lumen and acts as a substrate for bacteria, like Prevotella, that are able to degrade mucin [49-51]. Lastly, the presence of secreted immunoglobulin A (IgA) in the mucosa plays a critical and non-redundant role in monitoring the composition of microbiota [52]. Secretory IgA-deficient humans have been reported to exhibit reduced gut microbial diversity with significant shifts in the relative abundances of specific microbial taxa compared to matched controls [53].

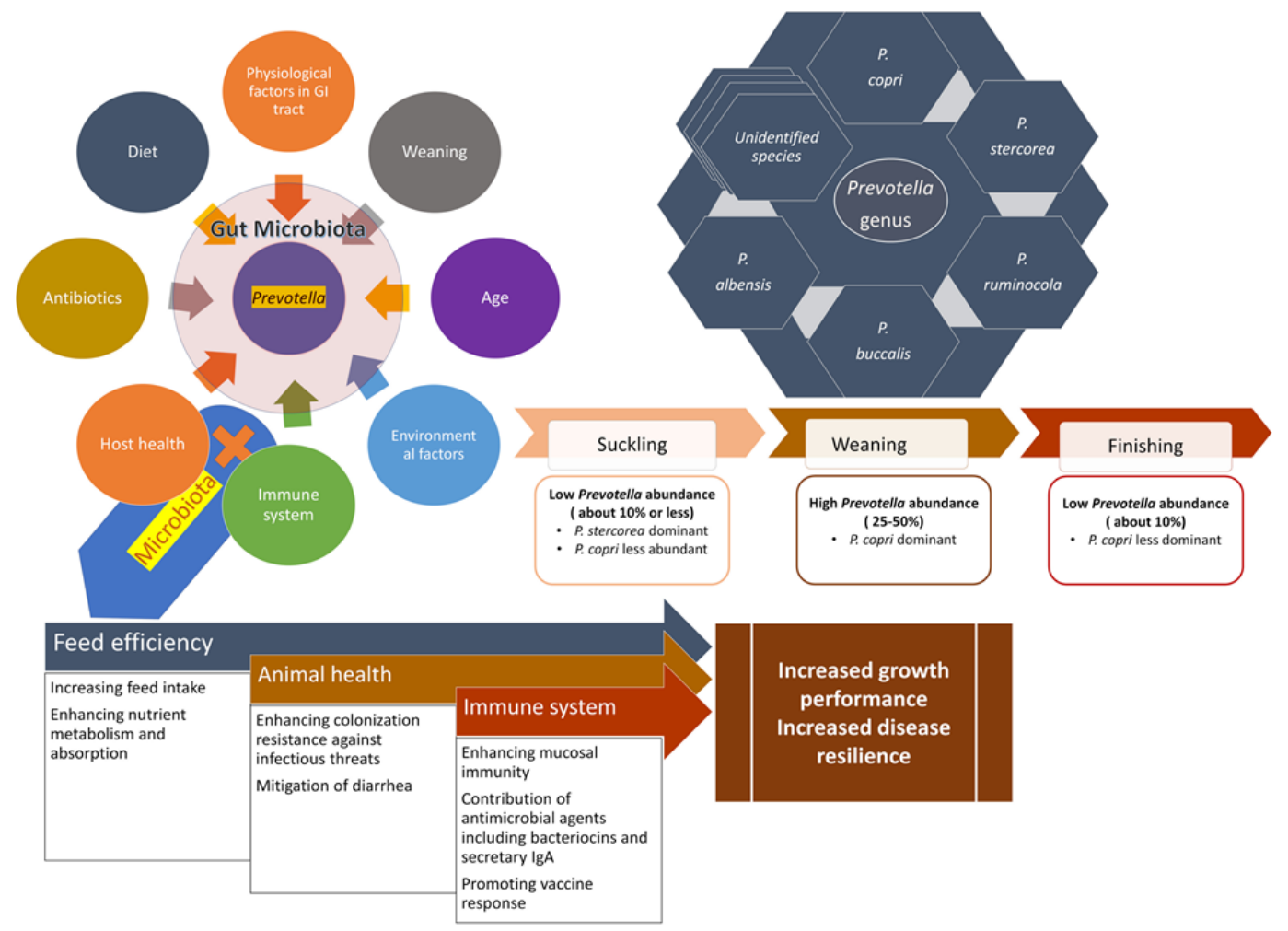

Figure 1. Schematic overview of the factors influencing the microbiota in gastrointestinal tract (GIT) of pig and the changes in relative abundance of Prevotella at different stage of pig growth, as well a hypothetical roles of Prevotrella spp. in mediating animal performance and health. The relative abundance of Prevotella spp. is influenced by many factors that shape gut microbiota. Under the symbiotic relationship with the host, gut microbiota mediates feed efficiency, immune system development, and host health in pigs. As a principal genus of the gut microbiota, Prevotella spp. are major contributors to host physiology. There are more than a dozen different species within the genus Prevotella present in the pig GIT, and their abundance changes with growth stage.

In addition to the physiological conditions specific to each of the GIT sections, the overall community structure and diversity of pig gut microbiota are shaped by other factors such as 
age, diet, and management practices. Longitudinal studies revealed that the pig gut microbiota undergoes significant changes in terms of community structure and composition from birth to market [12,54]. At the neonatal stage, the small intestinal microbiota is dominated by Lactobacillus, Escherichia/Shigella, and Bacteroides, while large intestinal microbiota is dominated by Prevotella [55]. However, upon weaning, both small and large intestines are dominated by Prevotella [55]. In comparison to large intestine, Prevotella is not as dominant in the small intestine [14]. The primary factor that can induce significant changes in the gut microbiota from birth to market across all different growth stages is diet, accounting for up to $34 \%$ of variations observed in pig gut microbiota [12]. Besides diet, management practices such as antibiotic treatment and housing are other important factors influencing the pig gut microbiota structure and diversity [56]. Antibiotics are commonly used in pig production to treat or prevent diseases and to improve feed efficiency [57]. However, increasing evidence suggest that the use of antibiotics may disrupt the GIT microbiota structure and function by eliminating the susceptible microbial population and leaving behind resistant strains that can continue to propagate and may be implicated in the development of drug-resistant infections $[15,56]$. The environment the pigs live in may also have an impact on the pig gut microbiota. For example, pigs raised in complex straw-based housing environment harbor a significantly distinct gut microbiota compared to those raised under simple-slatted housing environment in terms of community structure and composition [58].

Due to the numerous factors that shape the pig gut microbiota, the symbiotic relationship between the gut microbiota and the host is often disrupted, resulting in compromised host health and metabolism [3]. Thus, restoring such homeostasis through the manipulation of the gut microbiota holds great potential to improve pig health. The results of the FMT-based studies have suggested that modulation of the gut microbiota using FMT may enhance growth performance and disease resilience in pigs [11]. Of note, one of the significant changes observed in pig gut microbial composition in response to FMT is a significant increase in Prevotella [59], indicating that this genus may be involved in FMT-mediated changes in host phenotype in recipient animals.

\section{Prevotella within the Gut Microbial Community of Pigs}

\subsection{Taxonomy and a Brief History of the Genus Prevotella}

The genus Prevotella was created in 1990 by Shah and Collins [60] after evidence warranted reclassification from the genus Bacteroides. Under the new genus Prevotella, named after French microbiologist A.R. Prevot, 16 Gram-negative obligate anaerobic species of Prevotella were classified. The species that were transferred to the new genus Prevotella were quite distinct in terms of ecological, biological, and chemical characteristics from those of the genus Bacteroides. For example, these Prevotella species were first obtained from the oral cavity, upper respiratory tract, and urogenital tract, and they were deemed moderately fermentative, sensitive to bile salts, and lacked enzymes such as glucose-6-phosphate dehydrogenase (G6PDH) [60]. In contrast Bacteroides species, mainly isolated from the GIT, were fermentative, tolerant to bile salts, and possessed G6PDH [60].

Currently, there are approximately 51 validated species belonging to the genus Prevotella [61] (Table 1). These species are known to colonize throughout the host primarily in the oral cavity, upper respiratory tract, urogenital tract, and the GIT [61] (Table 1). The type of species within the Prevotella genus, P. melaninogenica, was initially isolated from the human oral cavity [60]. Of the species not initially isolated from humans, P. albensis, P. brevis, P. bryantii and P. ruminicola were all isolated from ruminants; $P$. pectinovora from pig feces; $P$. falsenii from the oral cavity of monkeys; and P. paludivivens from plant residue and rice roots $[62,63]$. Recently, three novel species, P. muris, $P$. rodentium, and P. intestinalis, were isolated from mouse colonic content [64]. Interestingly, 16S rRNA gene sequencing results of samples derived from the gut of moths and marine deep sediments have been shown to have 98.8 and $99.3 \%$ sequence identity to P. copri and P. tannerae, respectively [62]. 
Given the presence of Prevotella species in diverse animal species, it is likely that the genus will continue to expand as more environments are explored.

Table 1. Summary of the species in the genus Prevotella ${ }^{1}$.

\begin{tabular}{|c|c|c|c|c|}
\hline Prevotella Species & $\begin{array}{c}\text { Associated with } \\
\text { Human Infections }{ }^{2}\end{array}$ & Presence in Pig GIT ${ }^{3}$ & Comment & References \\
\hline P. albensis & - & Yes & Initially isolated from ruminants & [65] \\
\hline P. amnii & - & - & - & [61] \\
\hline P. bergensis & Yes & Yes & - & [61] \\
\hline P. bivia & Yes & Yes & - & {$[61]$} \\
\hline P. brevis & - & - & Initially isolated from ruminants & [65] \\
\hline P. buccalis & Yes & Yes & - & {$[61]$} \\
\hline P. conceptionensis & Yes & - & - & {$[66]$} \\
\hline P. coporis & Yes & - & - & {$[61]$} \\
\hline P. copri & Yes & Yes & Highly abundant pig gut after weaning & {$[61]$} \\
\hline P. dentalis & Yes & Yes & 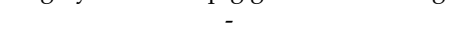 & [61] \\
\hline P. histicola & Yes & - & - & {$[61]$} \\
\hline P. falsenii & - & - & Initially isolated from monkey & [67] \\
\hline P. fusca & - & Yes & Human oral cavity & [68] \\
\hline P. intermedia & Yes & - & - & {$[61]$} \\
\hline P. intestinalis & - & - & Mouse colonic content & {$[64]$} \\
\hline P. loescheii & Yes & - & - & {$[61]$} \\
\hline P. massilliensis & - & - & - & {$[60]$} \\
\hline P. maculosa & - & Yes & - & [61] \\
\hline P. marshii & - & - & - & [61] \\
\hline P. melaninogenica & Yes & Yes & - & {$[60]$} \\
\hline P. micans & - & Yes & - & [61] \\
\hline P. multiformis & - & - & - & {$[60]$} \\
\hline P. oulora & - & - & - & [69] \\
\hline P. oulorum & Yes & Yes & - & [69] \\
\hline P. pallens & Yes & - & - & [61] \\
\hline P. pectinovora & - & - & Initially isolated from pig feces & [63] \\
\hline P. pleuritidis & - & - & - & {$[61]$} \\
\hline P. rodentium & - & - & Mouse colonic content & {$[64]$} \\
\hline P. ruminicola & Yes & - & Initially isolated from ruminants & [65] \\
\hline P. saccharolytica & & Yes & Human oral cavity & [70] \\
\hline P. salivae & Yes & Yes & - & [61] \\
\hline P. scopos & - & - & Human oral cavity & [68] \\
\hline P. shahii & - & Yes & - & {$[61]$} \\
\hline P. stercorea & - & Yes & More abundant in suckling piglet gut & {$[61]$} \\
\hline P. tannerae & - & - & $-\quad 100100$ & [61] \\
\hline P. timonensis & Yes & - & - & [61] \\
\hline P. veroralis & Yes & - & - & [61] \\
\hline P. zoogleoformans & Yes & - & - & {$[60]$} \\
\hline
\end{tabular}

${ }^{1}$ This list does not contain all the Prevotella species identified up to date, but it covers the list of species commonly reported from human, ruminants and pigs. ${ }^{2}$ The association with human infections was determined based on the information reported by Jousimies-Somer and Summanen [71], Ulger Toprak et al. [66] and Maeda [72]. ${ }^{3}$ Based on the operational taxanomic units (OTUs) assigned to ( $>97 \%$ sequence similarity) different Prevotella species. These data were derived from the pyrosequencing of 16S rRNA genes from stomach, ileum and colon samples of weaned piglets [73].

\subsection{Presence and Abundance of Prevotella along the Pig Gastrointestinal Tract}

Overall, Prevotella is the most predominant genus present in the GIT of pigs $[14,44,55]$. According to a meta-analysis performed on 20 publicly available data sets from high-throughput $16 \mathrm{~S}$ rRNA gene 
sequencing studies of the pig gut microbiota, Prevotella was identified as the most predominant genus within the GIT of pigs, with a mean relative abundance of $17.3 \%$ [14]. This meta-analysis also identified that Prevotella was detected with high frequency $(>97 \%)$ in samples that originated from gastric mucosa, duodenum, duodenal mucosa, jejunal mucosa, ileal mucosa, cecal mucosa, colon, colonic mucosa, and feces. Another longitudinal study showed that Prevotella was identified as the most predominant genus in the cecum, colon and rectum of pigs on days $7,21,28,35,120$, and 180 of age [55]. Collectively, these studies highlight that the genus Prevotella is an important member of both the upper and lower GI microbiotas in pigs. Although the specific functional properties of Prevotella spp. along the different GIT sections remain to be defined, it is likely that Prevotella spp. are functionally different between upper and lower GIT of pigs. The abundance of Prevotella spp. may also be different among the luminal and mucosal bacterial communities at some GI locations. Looft et al. [15] observed that mucosal microbiota harbored significantly greater abundance of Prevotella compared to luminal microbiota in the same site of small intestine (ileum, $9.3 \%$ vs. $0.01 \%$ ) in adult pigs. In the large intestine, however, Prevotella was found to be equally abundant in both luminal and mucosal microbiota compartments [15]. Of note, most data on Prevotella abundance are proportional, rather than quantitative, which sometimes limits interpretation.

The abundance of Prevotella in the pig GIT fluctuates with growth stages. Prevotella spp. are less abundant during the suckling and nursery stages but become more dominant during the growing and finishing stages after weaning [12,19,74-76]. In 2018, Guevarra et al. [74] evaluated the bacterial communities in fecal samples collected from 10 healthy piglets just prior to weaning ( $21 \mathrm{~d}$ of age) and one week after weaning ( $28 \mathrm{~d}$ of age) using $16 \mathrm{~S}$ rRNA gene sequencing, and they found that Prevotella increased from $12.9 \%$ to $57 \%$ over that period. In addition, Mach et al. [19] found that the relative abundance of Prevotella was 1\% in suckling piglets (d 14), 27\% within first week post weaning (d 36), and continued to increase in the subsequent 5 weeks $(31 \%, 41 \%, 43 \%$ on days 48,60 , and 70 , respectively). However, the fecal microbiota of sows harbored only about $8 \%$ Prevotella, indicating that there may be a point where relative abundance begins to decline.

Switching from milk-based to complex plant-based diets at weaning results in an abrupt change in the carbohydrate composition of the pig diet [77]. As a result, the microbial composition shifts towards microbes that can metabolize such substrates [77]. Metagenomic studies have shown significant alterations in the functional capacity of gut microbiota following the ingestion of complex plant-derived glycans, with greater abundance of genes involved in xylose utilization, mannose metabolism, and L-rhamnose utilization $[74,78,79]$. Species within the genus Prevotella can breakdown the plant cell wall through enzymes such as xylanases, mannanases and $\beta$-glucanases $[19,80]$. Thus, the dramatic changes in Prevotella abundance upon weaning is likely an important contributor to alteration of the overall function of gut microbiota.

\subsection{Different Prevotella Species Present in the Pig Gastrointestinal Tract}

Among the Prevotella species listed in Table 1, about $50 \%$ of these species have been reported in the pig GIT. The most frequently identified Prevotella species in samples from the pig GIT are P. copri, P. stercorea and P. ruminicola $[7,12,19,81,82]$. Nursing piglets may harbor more P. stercorea in the first 3 weeks of life while it depletes as the piglets grow [12]. P. copri, however, is present during the nursing period at low abundances, but increases drastically upon weaning, and continues to be more abundant in piglets at the nursery and growing stages while decreasing in the finishing stage [12]. Due to the fact that most of the studies characterizing the gut microbiota in pigs are based on 16S rRNA gene sequencing, which limits the identification of bacteria at the species level, there is inadequate information with respect to the complete survey of the different Prevotella species within the GIT. This may be informed by both metagenome assembled genomes as well as whole genome sequencing of new isolates. 


\section{Prevotella in Feed Efficiency and Growth Performance}

Regulation of feed intake and feeding behavior by the gut microbiota has recently been identified in pigs (Figure 1 and Table 2). Certain taxa including Prevotella spp. have been linked to microbiome-mediated feed intake in pigs. For example, results from 16S rRNA gene amplicon sequencing of fecal samples obtained from 280 commercial Duroc pigs revealed that the pigs that harbored a Prevotella-predominant enterotype had significantly higher average daily feed intake (ADFI) compared to the pigs characterized by the Treponema enterotype [18]. In this study, among the 18 OTUs that exhibited strong positive association with ADFI, 67\% were assigned to the genus Prevotella. Moreover, the network analysis performed on the ADFI-associated OTUs showed that Prevotella was a hub bacterium in the co-abundance network. Thus, it is possible that Prevotella spp. may promote feed intake in pigs, warranting further research into the manipulation of gut Prevotella to enhance feed intake and thereby promote growth performance. There is currently no proposed or demonstrated mechanism through which Prevotella increases feed intake, and Prevotella enrichment may be a product of increased feed intake rather than a driver of feed intake.

Other studies suggest that Prevotella-enriched gut microbiota may enhance growth performance in pigs (Table 2). Mach et al. [19] reported that, after weaning, the gut microbiota of healthy piglets $(n=31)$ were clustered into two different enterotypes (unclassified Ruminococcaceae or Prevotella-enriched enterotypes). Although the piglets in the Prevotella cluster exhibited lower growth rates during suckling, these animals showed higher body weight and average daily gain compared to animals belonging to the Ruminococcaceae cluster. The authors argued that the increased growth performance in Prevotella-enriched animals post weaning might be due to the ability of Prevotella to ferment complex dietary polysaccharides, which ultimately increases energy harvest, though not measured in the study. In addition, Ramayo-Caldas et al. [17] identified a gut microbial ecosystem structure linked with growth traits in pigs. They constructed two networks at the genus and OTU levels based on 16S rRNA sequencing data from the fecal samples of a cohort of 518 healthy 60 -day old pigs. Within network interactions, there was a strong co-exclusion between Prevotella and Ruminococcus genera. The piglet samples were clustered into two enterotype-like groups, which were dominated by either Ruminococcus and Treponema (PEA), or Prevotella and Mitsuokella (PEB). The animals that clustered into the PEB group had significantly greater body weight at 60 days of age and average daily gain compared to the PEA group, indicating a positive link between Prevotella predominant gut microbiota and favorable growth traits in pigs. This is further supported by Kiros et al. [83], who observed a positive correlation between piglet average daily gain and the abundance of Prevotella in piglets that received a diet supplemented with high yeast (Saccharomyces cerevisiae). Wang et al. [12] also identified Prevotella spp. (Prevotella copri and several unclassified Prevotella OTUs) as among the top 50 growth performance-associated taxa at suckling, nursing, growing, and finishing stages.

In contrast, there are some studies indicating that the abundance of Prevotella spp. is inversely correlated with feed efficiency in pigs. Tan et al. [79] observed a distinctive microbial structure and composition of cecal microbiota between low and high feed efficient (FE) pigs. Although Prevotella was the most enriched genus in both groups, low FE pigs harbored significantly higher abundance of Prevotella sp. CAG:604 taxa compared to high FE pigs. The authors suggested that the species Prevotella sp. CAG:604 might be a potential biomarker for distinguishing between the cecum microbiota of high and low FE groups. Thus, certain Prevotella species in the GIT may have adverse effects on the growth traits of pigs. Notably, these effects may be species or strain specific rather than common across all Prevotella spp. Another study also reported that the group of pigs that had low feed conversion ratio (FCRs) were colonized by greater abundances of taxa within the Prevotellaceae family in the ileum than high FCR animals [84]. In addition, Unno et al. [85] observed similar negative correlations between host weight and the abundance of Prevotellaceae family within the GIT. Furthermore, Yang et al. [82] evaluated the association of fecal microbiota with feed efficiency in 280 commercial Duroc pigs and reported that the pigs that clustered into the Treponema-dominant enterotype tended to have lower residual feed intake (RFI) values than those clustered into the Prevotella-dominant enterotype. 
Table 2. The summary of studies $(\mathrm{n}=11)$ showing the potential association of gut Prevotella with growth performance (positive) and diarrhea (negative) in pigs (determined by high throughput sequencing techniques).

\begin{tabular}{|c|c|c|c|c|c|c|c|c|}
\hline $\begin{array}{c}\text { Study } \\
\text { Categories }\end{array}$ & Animals & $\begin{array}{c}\text { Country of } \\
\text { Origin } \\
\end{array}$ & $\begin{array}{l}\text { Collected } \\
\text { Samples }\end{array}$ & Point of Sample Collection & Samples Processed for & Prevotella Abundance & Main Findings & References \\
\hline \multirow{5}{*}{ 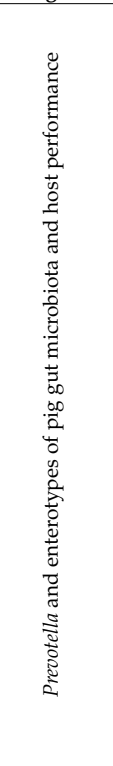 } & $\begin{array}{l}\text { A cohort of } 953 \text { pigs from a } F_{6} \\
\text { population of heterogeneous } \\
\text { pig cross }\end{array}$ & China & Fecal & $\begin{array}{l}\text { At the ages of } 25,120 \text { and } 240 \text { days, } \\
\text { which represented the time of } \\
\text { preweaning, mid-stage of fattening } \\
\text { and slaughtering (weaned at } d 28 \text { ) }\end{array}$ & $\begin{array}{l}\text { 16S rRNA gene sequencing } \\
\text { (V3-V4); } \\
\text { Illumina MiSeq }\end{array}$ & $\begin{array}{l}\text { Day } 25 \text { (preweaning): Fusobacterium vs. } \\
\text { Prevotella dominant enterotypes } \\
\text { Days } 80,120 \text { and } 240 \text { : Treponema vs. } \\
\text { Prevotella-dominant enterotypes }\end{array}$ & $\begin{array}{l}\text { Besides the piglets, even some adult pigs } \\
\text { switched putative enterotypes between ages }\end{array}$ & [16] \\
\hline & & & & & & $\begin{array}{l}\text { At all sampling time points, Prevotella } \\
\text { was most abundant and served as one } \\
\text { of the two main network hubs }\end{array}$ & $\begin{array}{l}\text { The topological features of phylogenetic } \\
\text { cooccurrence networks, including scale, } \\
\text { stability and complexity were increased } \\
\text { along with the age }\end{array}$ & \\
\hline & A total of 575 Large White pigs & France & Fecal & At the age of 60 days (weaned at $d 28$ ) & $\begin{array}{l}\text { 16S rRNA gene sequencing } \\
\text { (V3-V4); } \\
\text { Roche } 454 \text { GS FLX Titanium }\end{array}$ & $\begin{array}{l}\text { Ruminococcus and Treponema vs. } \\
\text { Prevotella and Mitsuokella-driven } \\
\text { enterotype (PEA vs. PEB) }\end{array}$ & $\begin{array}{l}\text { Diversity analysis revealed a significantly } \\
\text { higher level of alpha-diversity and richness } \\
\text { for PEA than for PPB } \\
\text { Animals that clustered with the PEB were } \\
\text { on average } 850 \mathrm{~g} \text { heavier and had an extra } \\
\text { average daily gain (ADG) of } 17.9 \mathrm{gg} \text { per day } \\
\text { than those that clustered with the PEA } \\
\text { Showed the link between microbial } \\
\text { ecosystems and pig growth traits }\end{array}$ & [17] \\
\hline & 280 commercial Duroc pigs & China & Fecal & At the age of 140 days (weaned at $d 28$ ) & $\begin{array}{l}\text { 16S rRNA gene sequencing } \\
\text { (V4); } \\
\text { Illumina MiSeq }\end{array}$ & $\begin{array}{l}\text { Prevotella vs. Treponema- predominant } \\
\text { enterotypes }\end{array}$ & $\begin{array}{l}12 \text { out of the } 18 \text { OTUs positively associated } \\
\text { with the average daily feed intake (ADFI) } \\
\text { were annotated to Prevotella, and Prevotella } \\
\text { was the hub bacteria in the co-abundance } \\
\text { network. These results suggest that } \\
\text { Prevotella might be a keystone bacterial } \\
\text { taxon for increasing host feed intake. }\end{array}$ & [18] \\
\hline & 1039 pigs & USA & Rectal swabs & $\begin{array}{l}\text { At weaning }(18.6 \pm 1.09 \text { days), week } \\
15 \text { (1118.2 } \pm 1.18) \text { days, and off-test } \\
(196.4 \pm 7.86 \text { days })\end{array}$ & $\begin{array}{l}\text { 16S rRNA gene sequencing } \\
\text { (V4); } \\
\text { Illumina MiSeq }\end{array}$ & $\begin{array}{l}\text { At weaning: Prevotella }(6.78 \%) \text { and the } \\
\text { 7th predominant genus; week } 15: \\
\text { Prevotella }(13.1 \%) \text {, and the } 1 \mathrm{st} \\
\text { predominant genus; off-test (at } \\
\text { slaughtering): Prevotella }(6.74 \%) \text {, and } \\
\text { the 2nd predominant genus }\end{array}$ & $\begin{array}{l}\text { Prevotella dominant enterotype was } \\
\text { observed at weaning stage. However, no } \\
\text { significant correlations between any } \\
\text { enterotypes at weaning and average daily } \\
\text { gain were detected }\end{array}$ & [43] \\
\hline
\end{tabular}


Table 2. Cont

\begin{tabular}{|c|c|c|c|c|c|c|c|c|}
\hline $\begin{array}{c}\text { Study } \\
\text { Categories }\end{array}$ & Animals & $\begin{array}{l}\text { Country of } \\
\text { Origin }\end{array}$ & $\begin{array}{l}\text { Collected } \\
\text { Samples }\end{array}$ & Point of Sample Collection & Samples Processed for & Prevotella Abundance & Main Findings & References \\
\hline \multirow{3}{*}{ 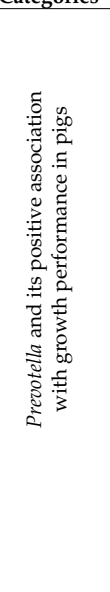 } & 18 pigs & USA & Rectal swabs & $\begin{array}{l}\text { During lactation (days } 0,11, \\
20, \text {, nursery ( } 27,33,41,50, \\
61), \text { growing (d } 76,90,104, \\
\text { 116), and finishing (d 130, 146, } \\
\text { 159, 174) stages }\end{array}$ & $\begin{array}{l}16 \mathrm{~S} \text { rRNA gene sequencing } \\
\text { (V4); } \\
\text { Illumina Miseq }\end{array}$ & $\begin{array}{l}\text { Among the top } 30 \text { taxa, } \\
11 \text { belong to genus } \\
\text { Prevotella, the most } \\
\text { diverse and dominant } \\
\text { genus throughout most } \\
\text { of the stages, especially } \\
\text { after the introduction of } \\
\text { solid feed }\end{array}$ & $\begin{array}{l}\text { Prevotetlla spp. (Prevotella copri and several unclassified } \\
\text { Prevotella OTUs) were identified as one of the top } 50 \\
\text { growth performance-associated taxa at lactation, } \\
\text { nursing, growing and finishing stages }\end{array}$ & [12] \\
\hline & 31 healthy piglets & France & Fecal & $\begin{array}{l}\text { At the ages of } 14,36,48,60 \text { and } \\
70 \text { days (weaned at } d 28 \text { ) }\end{array}$ & $\begin{array}{l}\text { 16S rRNA gene sequencing } \\
\text { (V3-V4); } \\
\text { Roche 454 } \\
\text { GS FLX Titanium }\end{array}$ & $\begin{array}{l}\text { After weaning, the } \\
\text { microbiota composition } \\
\text { coevolved with their } \\
\text { hosts towards two } \\
\text { different clusters: } \\
\text { unclassified } \\
\text { Ruminococcaceae vs. } \\
\text { Prevotella }\end{array}$ & $\begin{array}{l}\text { Prevotella cluster was positively correlated with luminal } \\
\text { secretory IgA concentrations, and body weight }\end{array}$ & [19] \\
\hline & $\begin{array}{l}\text { A total of } 48 \text { piglets (control vs. } \\
\text { low vs. high yeast } \\
\text { supplemented groups, } n=16 \text { ) }\end{array}$ & Canada & Cecum content & $\begin{array}{l}\text { At the age of } 28 \text { days (at } \\
\text { euthanization); body weight } \\
\text { measured at } 1,3,7,10,17,24 \\
\text { and } 28 \text { days }\end{array}$ & $\begin{array}{l}\text { 16S rRNA gene sequencing } \\
\text { (V1-V3); } \\
\text { Roche } 454 \text { FLX Titanium }\end{array}$ & $\begin{array}{l}\text { Relative abundance of } \\
\text { Prevotella genus in } \\
\text { pigilets receiving low or } \\
\text { high yeast } \\
\text { supplementation was } \\
0.046 \text { and } 3.07 \% \text {, } \\
\text { respectively }\end{array}$ & $\begin{array}{l}\text { Partial least squares analysis showed that piglet } \\
\text { average daily gain (ADG) was positively correlated } \\
\text { with genus } \\
\text { Prevotella in the high yeast group }\end{array}$ & [83] \\
\hline
\end{tabular}


Table 2. Cont.

\begin{tabular}{|c|c|c|c|c|c|c|c|c|}
\hline $\begin{array}{c}\text { Study } \\
\text { Categories }\end{array}$ & Animals & $\begin{array}{c}\text { Country of } \\
\text { Origin }\end{array}$ & $\begin{array}{l}\text { Collected } \\
\text { Samples }\end{array}$ & Point of Sample Collection & Samples Processed for & Prevotella Abundance & Main Findings & References \\
\hline \multirow{5}{*}{ 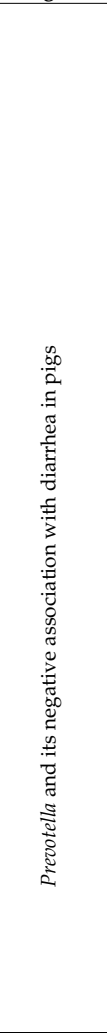 } & $\begin{array}{l}20 \text { piglets were weaned in poor } \\
\text { housing conditions to } \\
\text { challenge their susceptibility to }\end{array}$ & France & Fecal & $\begin{array}{l}\text { At the age of } 7,14,21,30,38 \\
\text { and } 47 \text { days }\end{array}$ & $\begin{array}{l}\text { 16S rRNA gene sequencing } \\
\text { (V1-V3); } \\
\text { Illumina MiSeq }\end{array}$ & $\begin{array}{l}\text { Prevotellaceae families were } \\
\text { increased in healthy pigs } \\
\text { compared to diarrheic pigs } \\
\text { At the genus level, the higher } \\
\text { abundance of Roseburia, } \\
\text { Prevotella and genera } \\
\text { belonging to Ruminococcaceae } \\
\text { was increased in healthy pigs }\end{array}$ & $\begin{array}{l}\text { The higher abundance of Prevotella may contribute to allowing } \\
\text { healthy pigs better adapt to post-weaning dietary conditions, } \\
\text { thereby mitigating the risk of developing diarrhea }\end{array}$ & [10] \\
\hline & 85 commercial piglets & China & Anal swab & $\begin{array}{l}\text { During the lactation ( } 0-19 \text { days } \\
\text { old), weaning ( } 20-21 \text { days old), } \\
\text { and post-weaning periods } \\
\text { (22-40 days) }\end{array}$ & $\begin{array}{l}\text { 16S rRNA gene sequencing } \\
\text { (V4); } \\
\text { Illumina Miseq }\end{array}$ & $\begin{array}{l}\text { Prevotellla was the one of the } \\
11 \text { genera whose abundance } \\
\text { was significantly higher in } \\
\text { non-diarrheic piglets } \\
\text { compared to diarrheic piglets }\end{array}$ & $\begin{array}{l}\text { Prevotellacecea } \\
\text { UCG-003 was identified as a key node in non-diarrheic piglets } \\
\text { upon co-correlation network analysis }\end{array}$ & [86] \\
\hline & & & & & & $\begin{array}{l}\text { The relative abundances of } \\
\text { OTUs belonging to } \\
\text { Prevotella } 2 \text { and Prevotella } 9 \\
\text { were } 0.789 \% \text { and } 0.849 \% \\
\text { from diarrheic piglets, and } \\
1.787 \% \text { and } 1.692 \% \text { in the } \\
\text { non-diarrheic samples }\end{array}$ & & \\
\hline & $\begin{array}{l}14 \text { piglets from healthy and } \\
\text { porcine epidemic diarrhea } \\
\text { virus (PEDV) } \\
\text { infection-diagnosed group } \\
(\mathrm{n}=7)\end{array}$ & $\begin{array}{l}\text { South } \\
\text { Korea }\end{array}$ & Fecal & Not provided & $\begin{array}{l}\text { 16S rRNA gene sequencing } \\
\text { (V3); } \\
\text { Illumina MiSeq }\end{array}$ & $\begin{array}{l}\text { Relative abundance of most } \\
\text { commensal bacteria } \\
\text { including Prevotella and } \\
\text { Faecalibacterium) in healthy } \\
\text { pigs was decreased following } \\
\text { dysbiosis induced } \\
\text { by PEDV infection }\end{array}$ & $\begin{array}{l}\text { Reduction of these commensal bacteria including Prevotella } \\
\text { may have implications in pathogenesis of PVDV-associated } \\
\text { diarrhea in pigs }\end{array}$ & [87] \\
\hline & $\begin{array}{l}\text { 51 piglets, and among which } 41 \\
\text { piglets were orally challenged } \\
\text { with enterotoxigenic Escherichia } \\
\text { coli (ETEC) }\end{array}$ & China & Jejunal and fecal & $\begin{array}{l}\text { Fresh feces were collected from } \\
\text { day } 1 \text { to day } 5 \text { (post diarrea } \\
\text { infection (PDI)); while cecum } \\
\text { jejunal samples were collected } \\
\text { at day } 6 \text { PDI }\end{array}$ & $\begin{array}{l}\text { 16S rRNA gene sequencing } \\
\text { (not provided); } \\
\text { Illumina Miseq }\end{array}$ & $\begin{array}{l}\text { Healthy piglets had higher } \\
\text { abundance of Prevotella in the } \\
\text { feces, but lower Lactococcus in } \\
\text { the jejunum and lower } \\
\text { Escherichia/Shigella in the feces } \\
\text { compared to diarrheal piglets } \\
\text { Prevotella }(4.2,1.7 \text { to } 0.2 \%) \\
\text { decreased as the piglets were } \\
\text { transient from pre-diarrheic } \\
\text { state to diarrheic state } \\
\text { Compared to resistant } \\
\text { pigletst, the diarrheal piglet } \\
\text { harbored lower Prevotella }\end{array}$ & $\begin{array}{l}\text { ETEC-induced diarrhea is associated with the alteration of } \\
\text { intestinal microbiota, including lower } \\
\text { Bacteroidetes: Firmicitues ratio and microbiota diversity } \\
\text { in the jejunum and feces, and lower Prevotella in the feces, but } \\
\text { higher percentage of Lactococcus in the jejunum and } \\
\text { Escherichia/Shigella in the feces }\end{array}$ & [13] \\
\hline
\end{tabular}


Overall, the existing studies showing the positive associations of Prevotella with feed efficiency and growth performance in pigs outnumber those indicating a negative association with these animal traits (Table 2). However, these contradictory studies highlight the need to investigate the role of specific Prevotella spp. in feed efficiency in pigs. We can speculate that the specific Prevotella spp. or strains associated with positive and negative growth outcomes differ, however, mechanistic studies with controlled Prevotella colonization are needed to demonstrate a causal role in altering growth performance.

\section{Prevotella and Diarrhea in Pigs}

The gut microbiota can mediate the development of diarrhea in pigs, and it has been shown that animals that harbor higher Prevotella may have better protection against diarrhea (Table 2). Dou et al. [10] observed that healthy piglets, which were weaned in poor housing conditions to challenge their susceptibility to diarrhea, harbored gut microbiota enriched with Prevotellaceae, Lachnospiraceae, Ruminococcaceae and Lactobacillaceae compared to diarrheic piglets. Sun et al. [86] also reported that non-diarrheic piglets harbored significantly greater abundance of gut Prevotella compared to diarrheic piglets. Co-correlation network analysis revealed that Prevotellacea UCG-003 was the key bacterium in the non-diarrheic microbiota of piglets, whereas the genus Escherichia-Shigella was the core component of diarrheic microbiota. The inverse association of the abundance of Prevotella with the incidence of diarrhea in pigs is further supported by a study in which the higher abundances of Prevotella have also been reported in piglets affected by diarrhea. Neonatal piglets with diarrhea exhibited significant enrichment of Prevotella [82]. The increase in Prevotella abundance was correlated with the depletion of E. coli, and Lactobacillus, Enterococcus, Streptococcus and Clostridium in diarrheic piglets. Thus, the authors speculated, based also on observed changes in microbial functional gene profiles in diarrheic piglets, that dysbiosis of the gut microbiota may create an environment in the GIT that favors the proliferation of Prevotella in diarrheic conditions [82]. Similarly, another study that evaluated the longitudinal development of the gut microbiota in healthy and diarrheic piglets induced by age related dietary changes showed that Prevotella was in greater relative abundance in diarrheic piglets than in healthy piglets receiving early supplementary creep feed or sows' milk [88]. The weak negative correlation between Prevotella and Escherichia observed with diarrheic piglets suggested that the disruption of the competitive relationship between Prevotella and Escherichia may have implications in predisposing piglets to diarrhea [88].

While the role of Prevotella in pathogenesis of pig diarrhea warrants further research, the interactions of Prevotella with other commensals and the presence of different Prevotella species at different growth stages may have implications in dictating the role of Prevotella to be a diarrhea preventative or promotive. The Prevotella genus is certainly not exclusively beneficial, as many Prevotella spp. (Table 1) have been associated with infections within the oral cavity, lower respiratory tract, central nervous system, abdominal and female genital tract $[61,66]$. Thus, characterization of Prevotella at species or even strain level in gut microbiota may enhance conclusive understanding of the relationship between Prevotella and incidence of diarrhea in pigs. Again, controlled studies with exposures to specific Prevotella species or strains will be required to demonstrate a causal role.

\section{Prevotella and the Intestinal Immune System}

The intestinal microbiota is important for the development and modulation of the gut mucosal immune system in pigs $[89,90]$. Prevotella, being one of the most predominant genera among the intestinal bacteria in both pre-and post-weaned pigs, may contribute to the microbiota-induced mucosal immune development. Although there is limited information with respect to the impact of Prevotella on mucosal immunity in pigs, existing evidence derived from humans and other mammals suggests that Prevotella spp. may contribute to the maturation of mucosal immunity in several ways [91,92]. One possible way might be through its association with short chain fatty acid (SCFA)-mediated mucosal immune homeostasis. Prevotella produces acetate as an end product of anaerobic microbial 
fermentation in the intestine [64,93]. Acetate is utilized by other commensals such as Roseburia and Faecalibacterium to produce butyrate [91]. Butyrate is an important microbial-derived SCFA that has been shown to benefit intestinal development and maintenance, and immune defense functions in mammalian species [92]. Butyrate is a primary energy source of colonocytes, and it is also involved in mucosal immune development and priming the mucosal defense against infectious threats [94]. Microbial-derived butyrate has been shown to promote epithelial barrier function through IL-10 receptor-dependent repression of claudin-2 [95]. Studies have shown that the capacity of microbial SCFA production varies in Prevotella- versus Bacteroides-dominated gut microbiota [95]. From the same carbohydrate substrates, Prevotella-dominated microbiota produced different profiles of SCFAs, and produced 2-3 times more propionate than the Bacteroides-dominated microbiota [95].

The Prevotella-dominant enterotype has also been associated with higher production of secretory IgA in adult pigs compared to the Ruminococcaceae enterotype [19]. The gut secretes significant amounts of $\operatorname{IgA}$ antibody that serves as the first line of innate defense against invading pathogens [96]. Secretory IgA also facilitates effective communication between the commensal microbiota and the immune system by selective presentation of commensal species to tolerogenic dendritic cells, thereby restricting systemic adaptive response to resident commensals [52]. It has been demonstrated that Bacteroides fragilis relies on IgA response to occupy a defined mucosal niche that mediates stable colonization of the gut through exclusion of exogenous competitors [97]. The fact that Prevotella abundance associates with elevated fecal IgA as well as improved growth performance may support the possibility that increased IgA is stimulated by Prevotella to maintain a symbiotic relationship with the host. It is also possible that Prevotella does not induce an IgA response and simply benefits from elevated levels of secretory IgA. Studies exploring the detailed and mechanistic nature of Prevotella's association with an IgA response are warranted, as elevated IgA correlates with performance [19].

There are also some reports showing that piglets that harbor Prevotella-dominated gut microbiota may be more susceptible to develop chronic inflammatory disease (e.g., colitis). For example, Xiao et al. [98] reported that the fecal microbiota of piglets that were less resilient against dextran sulphate sodium-induced acute colitis contained significantly greater abundance of Prevotella ( $35 \%$ vs. $24 \%$ ) compared to the more resilient ones. Prevotella spp. have been reported to be involved in the pathogenesis of ulcerative colitis in humans [99], although not consistently. In addition, there is a growing body of evidence in humans suggesting a link between the increase in Prevotella spp. at the intestinal mucosal site to localized and systemic disease [30,64]. Iljazovic et al. [64] investigated the potential causal role of $P$. intestinalis nov. sp. strain in intestinal dysbiosis and inflammation. Colonization with $P$. intestinalis decreased IL-18 production, which exacerbated colonic inflammation in immunocompetent mice [64]. Strikingly, when recombinant IL-18 was administered back to these mice, colitis symptoms, including inflammation, were decreased [64]. This study highlights the need for mechanistic experiments to determine the causal role(s) Prevotella spp. play in the immune system, not only in mice, but in other models. Furthermore, multiple lines of evidence derived from human and mice studies suggest the potential role of Prevotella dominant intestinal microbiota in the development of autoimmune diseases such as Rheumatoid arthritis [72,100]. Thus, it is important to investigate the role of Prevotella spp. in the development of intestinal inflammatory disorders in pigs.

It has been also suggested that an increase in Prevotella spp. in the intestinal tract of pigs may have a negative impact on the integrity of the intestinal mucus layer, and increased abundance of Prevotella spp. has been associated with penetrable mucus [101]. Some Prevotella spp. can degrade sulfated mucin glycans and thereby may affect the mucus layer [51,102]. In addition, Prevotella copri has been identified to act as modulator of infection caused by foodborne pathogen Listeria monocytogenes [103]. Precolonization of germ-free mice with Prevotella copri strain resulted in a significantly thinner mucus layer and higher degree of intestinal inflammation in mice following Listeria monocytogenes inoculation compared to those preinoculated with other commensal bacteria (Bacteroides thetaiotaomicron), suggesting that Prevotella copri may impair intestinal mucus barrier function, and therefore making the intestinal epithelial cells and local inflammation system more vulnerable to pathogen invasion [103]. However, 
the P. salivae strain did not exhibit any role in exacerbation of intestinal infection associated with Listeria monocytogenes [103]. To our knowledge, no study has investigated the role of Prevotella in mucus defense in pigs, but it is an area of research that future studies should investigate.

\section{Prevotella and Vaccine Response}

The potential role of gut microbiota in the regulation of host immune responses to vaccines has garnered more attention [104-106]. Various models have been used to study dysbiotic microbiota and vaccine response, such as germfree mice, antibiotic treated conventional mice [107], and gnotobiotic piglets transplanted with dysbiotic microbiota [108]. Both microbial composition and community diversity has been suggested to influence vaccine response [109]. While the underlying mechanisms by which gut microbiota influences vaccine response remains elusive, some evidence indicates a potential link between an increase in intestinal Prevotella and enhanced vaccine response. For example, a positive correlation was observed between Prevotella abundance and vaccine responsiveness in 28-day old piglets at the time of vaccination against Mycoplasma hyopneumoniae [110]. A parallel study performed in France on a separate population of pigs found the same association of Prevotella with elevated antibody titers following vaccination against M. hyopneumoniae [76]. According to the blood transcriptome analysis performed on samples obtained 2 days post-vaccination, biological processes associated with cell recruitment were more activated in high vaccine responders that harbored higher abundances of Prevotella [110]. Lipopolysaccharide originating from P. intermedia has been shown to act as an immunological adjuvant in mice vaccinated against hepatitis B virus [111]. While the data to date are correlational, it is tempting to speculate that increased Prevotella abundance may support a more robust response to vaccines through an adjuvant role.

\section{Prevotella and Bacterial Interactions}

Prevotella may also contribute to mucosal defense by direct or indirectly affecting antimicrobial peptide production in GIT. Strains within P. intermedia [112] and P. nigrescens [113] have been shown to produce bacteriocins. Most commensal bacteria residing within GIT have the ability to produce bacteriocins [114]. Prevotella, being highly interactive with other bacterial species in the gut, may also influence the capacity of bacteriocin production by other individual commensals. Multiple lines of evidence suggest that there is relatively strong species-species interaction network that exists between Prevotella spp. and other bacteria in pig GIT. Network analysis identified that the genus Prevotella exhibited close interconnectivity with many other taxa in both cooperative and competitive manners [18]. Wang et al. [12] identified P. corpi as key taxon that connects lactation and growing stage-specific bacterial clusters to one another, indicating that $P$. copri has close interactions with other gut microbial community members in both pre- and-post weaning pigs. Highly connected taxa have recently been termed as keystone taxa [20]. The keystone taxa drive the microbiome structure and functioning irrespective of their abundance across space and time [20]. Furthermore, microbial interactions shape host physiology, which was demonstrated by the fact that higher-order bacterial interactions accounted for a $28 \%$ increase in the life span of fruit flies [115]. Thus, Prevotella, being a highly connected genus within the GIT microbial community, may influence the overall metabolic function of gut microbiota. In addition to the network analysis, in vivo colonization studies also indicated that Prevotella interact with other beneficial and pathogenic bacteria within the gut. For example, a probiotic-based study suggested that species within Prevotella and Lactobacillus may have close interactions and thereby mutually support one another in the pig gut [74]. Interaction between gut P. copri and pathogenic bacteria Listeria monocytogenes has also recently been demonstrated in an infectious mouse model [103]. Interaction of Prevotella with other bacteria of the gut microbiota could be an important factor that influences how Prevotella behaves in different gut ecosystems and its interactions with the host. 


\section{Challenges and Future Opportunities Associated with Harnessing Prevotella to Improve Pig Health}

\subsection{Challenges}

The characterization of Prevotella spp. in the pig GIT has largely relied on culture independent methods, particularly 16S rRNA gene-based high throughput sequencing [14]. Although culture-independent methods enable researchers to study the abundance of Prevotella spp. in different GIT locations and their associations with animal performance and health outcomes at different growth stages, the information obtained by these methods is primarily limited to genus level. To date, the vast majority of studies are limited to correlations between the abundance of Prevotella and pig production and health, making it challenging to identify the role of Prevotella in defining host phenotype. The diversity of Prevotella species found in the GIT of pigs (e.g., P. copri, P. stercorea, P. ruminicula and P. oulorum) [12,73] and the known variation from symbiont to pathogen within the species indicate that genus level classification is insufficient. Even within a Prevotella species, multiple OTUs get classified as the same species [73]. For example, a study presented that 68 and 17 different OTUs were annotated to $P$. copri and P. stercorea, respectively [73]. Moreover, a recent comparative genomic analysis performed on more than 1000 P. copri genomes originating from the human gut represented by multiple host-geographies, disease and lifestyles revealed that $P$. copri is not a monotypic species but may be comprised of four different clades [116], all of which have the potential to reside solely or in combination, despite their distinct genomic diversity. Given the number of $P$. copri OTUs identified in many studies, it is likely that a P. copri complex also exists in the pig gut, however, this has not been explored. Given that antimicrobial and immunomodulation characteristics of bacteria are species and often strain specific [117], the functional features of Prevotella in the gut are also likely highly specific (Figure 1), which prompts the need for characterizing the role of most common Prevotella species in pigs (e.g., P. copri and P. stercorea) using metagenomic and culture dependent approaches. Apart from the application of whole genome sequencing for species and strain-level microbiome analysis [118,119], high throughput sequencing of the full 16S rRNA gene has shown the potential to provide taxonomic resolution of bacterial communities at species and strain level [120]. Thus, using the Pacific Biosciences (PacBio) RS II platform [120] to sequence the full 16S rRNA gene of the bacterial microbiota in pig GIT should be considered to identify the link between the host phenotype and specific Prevotella species or strains.

The strict obligate anaerobic nature of Prevotella spp. hinders their successful growth on non-selective growth media under standard anaerobic growth conditions. There is relatively limited information available with respect to culturing Prevotella species originating from the intestinal tract of pigs. Ghimire et al. [121] was able to culture and isolate P. copri and P. stercorea strains from the human fecal samples of healthy adults using a modified brain heart infusion (BHI) agar plate incubated at $37{ }^{\circ} \mathrm{C}$ for $48 \mathrm{~h}$ under the following anaerobic gas condition: $85 \% \mathrm{~N}_{2}, 10 \% \mathrm{CO}_{2}$ and $5 \% \mathrm{H}_{2}$ gas. Under the same media and growth conditions, these authors were able to isolate Prevotella from cecum and colon samples of adult Tamworth pigs. Having said this, the isolation frequency of Prevotella was relatively low (1.4\% of 500 colonies were identified as Prevotella), considering the relative abundance of Prevotella genus constituted $38 \%$ of the total microbiota in the donor pigs [122]. Thus, developing highly selective culture media and optimizing growth conditions for isolation of Prevotella species are needed.

In 2007, Hayashi et al. [123] first isolated P. copri and P. stercorea from feces of a healthy Japanese male using Eggerth Gagnon agar supplemented with 5\% $(v / v)$ horse blood. These plates were incubated for $48 \mathrm{~h}$ at $37^{\circ} \mathrm{C}$ in an atmosphere containing $100 \% \mathrm{CO}_{2}$. According to this study, the growth of Prevotella spp. may require an anaerobic atmosphere with higher concentrations of $10 \% \mathrm{CO}_{2}$ or higher. As such, a recent study identified that $P$. copri depends more heavily on the addition of $\mathrm{CO}_{2}$ or bicarbonate for biomass formation compared to Bacteroides spp. [93]. With this knowledge, our research team has been working to culture Prevotella species originating from the pig intestine. Using peptone yeast glucose (PYG, modified from the original media developed by Varel and Bryant [124]) media under 
anaerobic conditions containing $20 \% \mathrm{CO}_{2}$ and $80 \% \mathrm{~N}_{2}$ mixed gas, P. copri was successfully isolated from conventional sow feces. Given that various Prevotella species are present within the GIT of pigs, developing culture media and identifying optimal growth conditions that support the growth of multiple Prevotella species should be the focus of future research.

\subsection{Future Opportunities}

The increasing applications of meta-omics including shotgun metagenomics, metatranscriptomics, metaproteomics, and metabolomics in functional and translational microbiome research enable comprehensive characterization of the composition (at strain level), functional, and metabolic activities of complex microbiomes [125]. With continuing decline in the cost of these meta-omic approaches and rapid advances in data integration, there will be an increased application of the integrated meta-omics in studying pig gut microbiota. As a result, uncovering the role of gut microbiota in pig health and productivity will advance, ultimately providing a basis for microbiome-targeted strategies to be employed. Developing Prevotella spp.-based next-generation probiotics might be a logical first step to manipulate the Prevotella species of interest in pig gut and thereby improve feed efficiency and gut health. While there are no probiotics Prevotella spp. currently available for pigs, Prevotella bryantii strains (25A and 3G5) have been used as probiotics in early-lactation dairy cows and sheep to improve ruminal fermentation products and milk fat concentration [126,127]. Prevotella copri, the most predominant species in GIT of adult pigs, could be a good candidate for the development as a next-generation probiotic. Thus, the role of $P$. copri originating from the pig in fermentation dynamics and interaction with the host should be characterized in vitro and in vivo using cell culture, chemostat gut model systems and controlled colonization models including integrated multi-omics analysis.

\section{Conclusions}

Although much progress has been made in understanding the role of gut microbiota in pig health and productivity in recent years, this knowledge is still largely limited to the association of overall community diversity and composition with certain host phenotypes. Thus, identifying causational roles of individual members of the gut microbiota on host phenotype is essential to create strategies targeted at improving host health and productivity. Therefore, further investigation on the causational role of the species within Prevotella in regard to feed efficiency, immune response, and disease resilience in pigs will not only elucidate the principles that govern the gut microbiota and host interactions, but also provide important information to design microbiome-mediated strategies to achieve desired host phenotypes. In order to explicate the causal relationship between Prevotella spp. and the host, the application of controlled colonization models coupled with meta-omic techniques, and improved culture techniques are required.

Author Contributions: Writing-original draft preparation, S.A. and B.P.W.; writing—review and editing, S.A., H.L., P.M.M. and B.P.W. All authors have read and agreed to the published version of the manuscript.

Funding: This work was funded by Alberta Agriculture and Forestry, Genome Alberta and Genome Canada.

Acknowledgments: H.L. is the recipient of the Canadian Natural Science and Engineering Research Council (NSERC) Alexander Graham Bell Canada Graduate Scholarship-Master's. P.M.M. is the recipient of the Women and Children's Health Research Institute (WCHRI) Postdoctoral Fellowship through the Stollery Children's Hospital Foundation. B.P.W. is supported by the Canada Research Chair Program.

Conflicts of Interest: The authors declare no conflict of interest.

\section{References}

1. Patil, Y.; Gooneratne, R.; Ju, X.H. Interactions between host and gut microbiota in domestic pigs: A review. Gut Microbes 2020, 11, 310-334. [CrossRef] [PubMed]

2. McCormack, U.M.; Curião, T.; Buzoianu, S.G.; Prieto, M.L.; Ryan, T.; Varley, P.; Crispie, F.; Magowan, E.; Metzler-Zebeli, B.U.; Berry, D.; et al. Exploring a Possible Link between the Intestinal Microbiota and Feed Efficiency in Pigs. Appl. Environ. Microbiol. 2017, 83. [CrossRef] [PubMed] 
3. Fouhse, J.; Zijlstra, R.; Willing, P. The role of gut microbiota in the health and disease of pigs. Anim. Front. 2016, 6, 30-36. [CrossRef]

4. Willing, B.P.; Russell, S.L.; Finlay, B.B. Shifting the balance: Antibiotic effects on host-microbiota mutualism. Nat. Rev. Microbiol. 2011, 9, 233-243. [CrossRef] [PubMed]

5. Khosravi, A.; Mazmanian, S.K. Disruption of the gut microbiome as a risk factor for microbial infections. Curr. Opin. Microbiol. 2013, 16, 221-227. [CrossRef] [PubMed]

6. Pickard, J.M.; Zeng, M.Y.; Caruso, R.; Núñez, G. Gut microbiota: Role in pathogen colonization, immune responses, and inflammatory disease. Immunol. Rev. 2017, 279, 70-89. [CrossRef]

7. Fouhse, J.M.; Yang, K.; More-Bayona, J.; Gao, Y.; Goruk, S.; Plastow, G.; Field, C.J.; Barreda, D.R.; Willing, B.P. Neonatal Exposure to Amoxicillin Alters Long-Term Immune Response Despite Transient Effects on Gut-Microbiota in Piglets. Front. Immunol. 2019, 10, 2059. [CrossRef]

8. Li, J.; Yang, K.; Ju, T.; Ho, T.; McKay, C.A.; Gao, Y.; Forget, S.K.; Gartner, S.R.; Field, C.J.; Chan, C.B.; et al. Early life antibiotic exposure affects pancreatic islet development and metabolic regulation. Sci. Rep. 2017, 7, 41778. [CrossRef]

9. Schachtschneider, K.M.; Yeoman, C.J.; Isaacson, R.E.; White, B.A.; Schook, L.B.; Pieters, M. Modulation of systemic immune responses through commensal gastrointestinal microbiota. PLoS ONE 2013, 8, e53969. [CrossRef]

10. Dou, S.; Gadonna-Widehem, P.; Rome, V.; Hamoudi, D.; Rhazi, L.; Lakhal, L.; Larcher, T.; Bahi-Jaber, N.; Pinon-Quintana, A.; Guyonvarch, A.; et al. Characterisation of Early-Life Fecal Microbiota in Susceptible and Healthy Pigs to Post-Weaning Diarrhoea. PLoS ONE 2017, 12, e0169851. [CrossRef]

11. Canibe, N.; O'Dea, M.; Abraham, S. Potential relevance of pig gut content transplantation for production and research. J. Anim. Sci. Biotechnol. 2019, 10, 55. [CrossRef] [PubMed]

12. Wang, X.; Tsai, T.; Deng, F.; Wei, X.; Chai, J.; Knapp, J.; Apple, J.; Maxwell, C.V.; Lee, J.A.; Li, Y.; et al. Longitudinal investigation of the swine gut microbiome from birth to market reveals stage and growth performance associated bacteria. Microbiome 2019, 7, 109. [CrossRef] [PubMed]

13. Bin, P.; Tang, Z.; Liu, S.; Chen, S.; Xia, Y.; Liu, J.; Wu, H.; Zhu, G. Intestinal microbiota mediates Enterotoxigenic Escherichia coli-induced diarrhea in piglets. BMC Vet. Res. 2018, 14, 385. [CrossRef] [PubMed]

14. Holman, D.B.; Brunelle, B.W.; Trachsel, J.; Allen, H.K. Meta-analysis To Define a Core Microbiota in the Swine Gut. mSystems 2017, 2. [CrossRef] [PubMed]

15. Looft, T.; Allen, H.K.; Cantarel, B.L.; Levine, U.Y.; Bayles, D.O.; Alt, D.P.; Henrissat, B.; Stanton, T.B. Bacteria, phages and pigs: The effects of in-feed antibiotics on the microbiome at different gut locations. ISME J. 2014, 8, 1566-1576. [CrossRef] [PubMed]

16. Ke, S.; Fang, S.; He, M.; Huang, X.; Yang, H.; Yang, B.; Chen, C.; Huang, L. Age-based dynamic changes of phylogenetic composition and interaction networks of health pig gut microbiome feeding in a uniformed condition. BMC Vet. Res. 2019, 15, 172. [CrossRef] [PubMed]

17. Ramayo-Caldas, Y.; Mach, N.; Lepage, P.; Levenez, F.; Denis, C.; Lemonnier, G.; Leplat, J.J.; Billon, Y.; Berri, M.; Doré, J.; et al. Phylogenetic network analysis applied to pig gut microbiota identifies an ecosystem structure linked with growth traits. ISME J. 2016, 10, 2973-2977. [CrossRef]

18. Yang, H.; Yang, M.; Fang, S.; Huang, X.; He, M.; Ke, S.; Gao, J.; Wu, J.; Zhou, Y.; Fu, H.; et al. Evaluating the profound effect of gut microbiome on host appetite in pigs. BMC Microbiol. 2018, 18, 215. [CrossRef]

19. Mach, N.; Berri, M.; Estelle, J.; Levenez, F.; Lemonnier, G.; Denis, C.; Leplat, J.J.; Chevaleyre, C.; Billon, Y.; Dore, J.; et al. Early-life establishment of the swine gut microbiome and impact on host phenotypes. Environ. Microbiol. Rep. 2015, 7, 554-569. [CrossRef]

20. Banerjee, S.; Schlaeppi, K.; van der Heijden, M.G.A. Keystone taxa as drivers of microbiome structure and functioning. Nat. Rev. Microbiol. 2018, 16, 567-576. [CrossRef]

21. Precup, G.; Vodnar, D.C. Gut. Br. J. Nutr. 2019, 122, 131-140. [CrossRef] [PubMed]

22. Amaral, W.Z.; Lubach, G.R.; Proctor, A.; Lyte, M.; Phillips, G.J.; Coe, C.L. Social Influences on Prevotella and the Gut Microbiome of Young Monkeys. Psychosom. Med. 2017, 79, 888-897. [CrossRef] [PubMed]

23. Wang, J.; Lang, T.; Shen, J.; Dai, J.; Tian, L.; Wang, X. Core Gut Bacteria Analysis of Healthy Mice. Front. Microbiol. 2019, 10, 887. [CrossRef] [PubMed]

24. Lv, X.; Chai, J.; Diao, Q.; Huang, W.; Zhuang, Y.; Zhang, N. The Signature Microbiota Drive Rumen Function Shifts in Goat Kids Introduced to Solid Diet Regimes. Microorganisms 2019, 7, 516. [CrossRef] 
25. Chen, Y.; Ni, J.; Li, H. Effect of green tea and mulberry leaf powders on the gut microbiota of chicken. BMC Vet. Res. 2019, 15, 77. [CrossRef]

26. Stevenson, D.M.; Weimer, P.J. Dominance of Prevotella and low abundance of classical ruminal bacterial species in the bovine rumen revealed by relative quantification real-time PCR. Appl. Microbiol. Biotechnol. 2007, 75, 165-174. [CrossRef]

27. Kim, J.N.; Méndez-García, C.; Geier, R.R.; Iakiviak, M.; Chang, J.; Cann, I.; Mackie, R.I. Metabolic networks for nitrogen utilization in Prevotella ruminicola 23. Sci. Rep. 2017, 7, 7851. [CrossRef]

28. Wirth, R.; Kádár, G.; Kakuk, B.; Maróti, G.; Bagi, Z.; Szilágyi, Á.; Rákhely, G.; Horváth, J.; Kovács, K.L. The Planktonic Core Microbiome and Core Functions in the Cattle Rumen by Next Generation Sequencing. Front. Microbiol. 2018, 9, 2285. [CrossRef]

29. Gorvitovskaia, A.; Holmes, S.P.; Huse, S.M. Interpreting Prevotella and Bacteroides as biomarkers of diet and lifestyle. Microbiome 2016, 4, 15. [CrossRef]

30. Larsen, J.M. The immune response to Prevotella bacteria in chronic inflammatory disease. Immunology 2017, 151, 363-374. [CrossRef]

31. Valles-Colomer, M.; Falony, G.; Darzi, Y.; Tigchelaar, E.F.; Wang, J.; Tito, R.Y.; Schiweck, C.; Kurilshikov, A.; Joossens, M.; Wijmenga, C.; et al. The neuroactive potential of the human gut microbiota in quality of life and depression. Nat. Microbiol. 2019, 4, 623-632. [CrossRef] [PubMed]

32. De Filippis, F.; Pasolli, E.; Tett, A.; Tarallo, S.; Naccarati, A.; De Angelis, M.; Neviani, E.; Cocolin, L.; Gobbetti, M.; Segata, N.; et al. Distinct Genetic and Functional Traits of Human Intestinal Prevotella copri Strains Are Associated with Different Habitual Diets. Cell Host Microbe 2019, 25, 444-453. [CrossRef]

33. de Aquino, S.G.; Abdollahi-Roodsaz, S.; Koenders, M.I.; van de Loo, F.A.; Pruijn, G.J.; Marijnissen, R.J.; Walgreen, B.; Helsen, M.M.; van den Bersselaar, L.A.; de Molon, R.S.; et al. Periodontal pathogens directly promote autoimmune experimental arthritis by inducing a TLR2- and IL-1-driven Th17 response. J. Immunol. 2014, 192, 4103-4111. [CrossRef] [PubMed]

34. Nagaoka, K.; Yanagihara, K.; Morinaga, Y.; Nakamura, S.; Harada, T.; Hasegawa, H.; Izumikawa, K.; Ishimatsu, Y.; Kakeya, H.; Nishimura, M.; et al. Prevotella intermedia induces severe bacteremic pneumococcal pneumonia in mice with upregulated platelet-activating factor receptor expression. Infect. Immun. 2014, 82, 587-593. [CrossRef] [PubMed]

35. Yu, C.; Zhou, B.; Xia, X.; Chen, S.; Deng, Y.; Wang, Y.; Wu, L.; Tian, Y.; Zhao, B.; Xu, H.; et al. Prevotella copri is associated with carboplatin-induced gut toxicity. Cell Death Dis. 2019, 10, 714. [CrossRef]

36. Wang, M.; Donovan, S.M. Human microbiota-associated swine: Current progress and future opportunities. ILAR J. 2015, 56, 63-73. [CrossRef]

37. Walters, E.M.; Wells, K.D.; Bryda, E.C.; Schommer, S.; Prather, R.S. Swine models, genomic tools and services to enhance our understanding of human health and diseases. Lab Anim. 2017, 46, 167-172. [CrossRef]

38. Kinder, H.A.; Baker, E.W.; West, F.D. The pig as a preclinical traumatic brain injury model: Current models, functional outcome measures, and translational detection strategies. Neural Regen. Res. 2019, 14, 413-424. [CrossRef]

39. Hillman, E.T.; Lu, H.; Yao, T.; Nakatsu, C.H. Microbial Ecology along the Gastrointestinal Tract. Microbes Environ. 2017, 32, 300-313. [CrossRef]

40. Richards, J.; Gong, J.; de Lange, C. The gastrointestinal microbiota and its role in monogastric nutrition and health with an emphasis on pigs: Current understanding, possible modulations, and new technologies for ecological studies. Can. J. Anim. Sci. 2005, 85, 421-435. [CrossRef]

41. Isaacson, R.; Kim, H.B. The intestinal microbiome of the pig. Anim. Health Res. Rev. 2012, 13, 100-109. [CrossRef]

42. Leser, T.D.; Amenuvor, J.Z.; Jensen, T.K.; Lindecrona, R.H.; Boye, M.; Møller, K. Culture-independent analysis of gut bacteria: The pig gastrointestinal tract microbiota revisited. Appl. Environ. Microbiol. 2002, 68, 673-690. [CrossRef] [PubMed]

43. Lu, D.; Tiezzi, F.; Schillebeeckx, C.; McNulty, N.P.; Schwab, C.; Shull, C.; Maltecca, C. Host contributes to longitudinal diversity of fecal microbiota in swine selected for lean growth. Microbiome 2018, 6, 4. [CrossRef] [PubMed]

44. Crespo-Piazuelo, D.; Estellé, J.; Revilla, M.; Criado-Mesas, L.; Ramayo-Caldas, Y.; Óvilo, C.; Fernández, A.I.; Ballester, M.; Folch, J.M. Characterization of bacterial microbiota compositions along the intestinal tract in pigs and their interactions and functions. Sci. Rep. 2018, 8, 12727. [CrossRef] 
45. van Winsen, R.L.; Urlings, B.A.; Lipman, L.J.; Snijders, J.M.; Keuzenkamp, D.; Verheijden, J.H.; van Knapen, F. Effect of fermented feed on the microbial population of the gastrointestinal tracts of pigs. Appl. Environ. Microbiol. 2001, 67, 3071-3076. [CrossRef] [PubMed]

46. Jiménez, E.; Sánchez, B.; Farina, A.; Margolles, A.; Rodríguez, J.M. Characterization of the bile and gall bladder microbiota of healthy pigs. Microbiologyopen 2014, 3, 937-949. [CrossRef]

47. Begley, M.; Gahan, C.G.; Hill, C. The interaction between bacteria and bile. FEMS Microbiol. Rev. 2005, 29,625-651. [CrossRef] [PubMed]

48. Hofmann, A.F.; Eckmann, L. How bile acids confer gut mucosal protection against bacteria. Proc. Natl. Acad. Sci. USA 2006, 103, 4333-4334. [CrossRef]

49. Corfield, A.P. The Interaction of the Gut Microbiota with the Mucus Barrier in Health and Disease in Human. Microorganisms 2018, 6, 78. [CrossRef] [PubMed]

50. Schroeder, B.O. Fight them or feed them: How the intestinal mucus layer manages the gut microbiota. Gastroenterol. Rep. 2019, 7, 3-12. [CrossRef]

51. Wright, D.P.; Rosendale, D.I.; Robertson, A.M. Prevotella enzymes involved in mucin oligosaccharide degradation and evidence for a small operon of genes expressed during growth on mucin. FEMS Microbiol. Lett. 2000, 190, 73-79. [CrossRef] [PubMed]

52. Mathias, A.; Pais, B.; Favre, L.; Benyacoub, J.; Corthésy, B. Role of secretory IgA in the mucosal sensing of commensal bacteria. Gut Microbes 2014, 5, 688-695. [CrossRef] [PubMed]

53. Catanzaro, J.R.; Strauss, J.D.; Bielecka, A.; Porto, A.F.; Lobo, F.M.; Urban, A.; Schofield, W.B.; Palm, N.W. IgA-deficient humans exhibit gut microbiota dysbiosis despite secretion of compensatory IgM. Sci. Rep. 2019, 9, 13574. [CrossRef] [PubMed]

54. Le Sciellour, M.; Renaudeau, D.; Zemb, O. Longitudinal Analysis of the Microbiota Composition and Enterotypes of Pigs from Post-Weaning to Finishing. Microorganisms 2019, 7, 622. [CrossRef] [PubMed]

55. Liu, Y.; Zheng, Z.; Yu, L.; Wu, S.; Sun, L.; Xu, Q.; Cai, S.; Qin, N.; Bao, W. Examination of the temporal and spatial dynamics of the gut microbiome in newborn piglets reveals distinct microbial communities in six intestinal segments. Sci. Rep. 2019, 9, 3453. [CrossRef] [PubMed]

56. Zeineldin, M.; Aldridge, B.; Lowe, J. Antimicrobial Effects on Swine Gastrointestinal Microbiota and Their Accompanying Antibiotic Resistome. Front. Microbiol. 2019, 10, 1035. [CrossRef] [PubMed]

57. Lekagul, A.; Tangcharoensathien, V.; Yeung, S. Patterns of antibiotic use in global pig production: A systematic review. Vet. Anim. Sci. 2019, 7, 100058. [CrossRef]

58. Megahed, A.; Zeineldin, M.; Evans, K.; Maradiaga, N.; Blair, B.; Aldridge, B.; Lowe, J. Impacts of environmental complexity on respiratory and gut microbiome community structure and diversity in growing pigs. Sci. Rep. 2019, 9, 13773. [CrossRef]

59. McCormack, U.M.; Curião, T.; Wilkinson, T.; Metzler-Zebeli, B.U.; Reyer, H.; Ryan, T.; Calderon-Diaz, J.A.; Crispie, F.; Cotter, P.D.; Creevey, C.J.; et al. Fecal Microbiota Transplantation in Gestating Sows and Neonatal Offspring Alters Lifetime Intestinal Microbiota and Growth in Offspring. mSystems 2018, 3. [CrossRef]

60. Shah, H.N.; Collins, D.M. Prevotella, a new genus to include Bacteroides melaninogenicus and related species formerly classified in the genus Bacteroides. Int. J. Syst. Bacteriol. 1990, 40, 205-208. [CrossRef]

61. Wybo, I.; Soetens, O.; De Bel, A.; Echahidi, F.; Vancutsem, E.; Vandoorslaer, K.; Piérard, D. Species identification of clinical Prevotella isolates by matrix-assisted laser desorption ionization-time of flight mass spectrometry. J. Clin. Microbiol. 2012, 50, 1415-1418. [CrossRef] [PubMed]

62. Alauzet, C.; Marchandin, H.; Lozniewski, A. New insights into Prevotella diversity and medical microbiology. Future Microbiol. 2010, 5, 1695-1718. [CrossRef] [PubMed]

63. Nograšek, B.; Accetto, T.; Fanedl, L.; Avguštin, G. Description of a novel pectin-degrading bacterial species Prevotella pectinovora sp. nov., based on its phenotypic and genomic traits. J. Microbiol. 2015, 53, 503-510. [CrossRef] [PubMed]

64. Iljazovic, A.; Roy, U.; Gálvez, E.J.C.; Lesker, T.R.; Zhao, B.; Gronow, A.; Amend, L.; Will, S.E.; Hofmann, J.D.; Pils, M.C.; et al. Perturbation of the gut microbiome by Prevotella spp. enhances host susceptibility to mucosal inflammation. Mucosal Immunol. 2020. [CrossRef]

65. Avgustin, G.; Wallace, R.J.; Flint, H.J. Phenotypic diversity among ruminal isolates of Prevotella ruminicola: Proposal of Prevotella brevis sp. nov., Prevotella bryantii sp. nov., and Prevotella albensis sp. nov. and redefinition of Prevotella ruminicola. Int. J. Syst. Bacteriol. 1997, 47, 284-288. [CrossRef] [PubMed] 
66. Ulger Toprak, N.; Alida, C.M.V.; Urban, E.; Wybo, I.; Justesen, U.S.; Jean-Pierre, H.; Morris, T.; Akgul, O.; Kulekci, G.; Soyletir, G.; et al. Performance of mass spectrometric identification of clinical Prevotella species using the VITEK MS system: A prospective multi-center study. Anaerobe 2018, 54, 205-209. [CrossRef] [PubMed]

67. Sakamoto, M.; Kumada, H.; Hamada, N.; Takahashi, Y.; Okamoto, M.; Bakir, M.A.; Benno, Y. Prevotella falsenii sp. nov., a Prevotella intermedia-like organism isolated from monkey dental plaque. Int J. Syst. Evol. Microbiol. 2009, 59, 319-322. [CrossRef]

68. Downes, J.; Wade, W.G. Prevotella fusca sp. nov. and Prevotella scopos sp. nov., isolated from the human oral cavity. Int. J. Syst. Evol. Microbiol. 2011, 61, 854-858. [CrossRef]

69. Berger, P.; Adékambi, T.; Mallet, M.N.; Drancourt, M. Prevotella massiliensis sp. nov. isolated from human blood. Res. Microbiol. 2005, 156, 967-973. [CrossRef]

70. Downes, J.; Tanner, A.C.R.; Dewhirst, F.E.; Wade, W.G. Prevotella saccharolytica sp. nov., isolated from the human oral cavity. Int. J. Syst. Evol. Microbiol. 2010, 60, 2458-2461. [CrossRef]

71. Jousimies-Somer, H.; Summanen, P.R. Recent taxonomic changes and terminology update of clinically significant anaerobic gram-negative bacteria (excluding spirochetes). Clin. Infect. Dis. 2002, 35, S17-S21. [CrossRef] [PubMed]

72. Maeda, Y.; Kurakawa, T.; Umemoto, E.; Motooka, D.; Ito, Y.; Gotoh, K.; Hirota, K.; Matsushita, M.; Furuta, Y.; Narazaki, M.; et al. Dysbiosis Contributes to Arthritis Development via Activation of Autoreactive T Cells in the Intestine. Arthritis Rheumatol. 2016, 68, 2646-2661. [CrossRef]

73. Mann, E.; Schmitz-Esser, S.; Zebeli, Q.; Wagner, M.; Ritzmann, M.; Metzler-Zebeli, B.U. Mucosa-associated bacterial microbiome of the gastrointestinal tract of weaned pigs and dynamics linked to dietary calcium-phosphorus. PLoS ONE 2014, 9, e86950. [CrossRef] [PubMed]

74. Guevarra, R.B.; Hong, S.H.; Cho, J.H.; Kim, B.R.; Shin, J.; Lee, J.H.; Kang, B.N.; Kim, Y.H.; Wattanaphansak, S.; Isaacson, R.E.; et al. The dynamics of the piglet gut microbiome during the weaning transition in association with health and nutrition. J. Anim. Sci. Biotechnol. 2018, 9, 54. [CrossRef] [PubMed]

75. Han, G.G.; Lee, J.Y.; Jin, G.D.; Park, J.; Choi, Y.H.; Chae, B.J.; Kim, E.B.; Choi, Y.J. Evaluating the association between body weight and the intestinal microbiota of weaned piglets via 16S rRNA sequencing. Appl. Microbiol. Biotechnol. 2017, 101, 5903-5911. [CrossRef] [PubMed]

76. Munyaka, P.M.; Blanc, F.; Estellé, J.; Lemonnier, G.; Leplat, J.J.; Rossignol, M.N.; Jardet, D.; Plastow, G.; Billon, Y.; Willing, B.P.; et al. Discovery of Predictors of Mycoplasma hyopneumoniae Vaccine Response Efficiency in Pigs: 16S rRNA Gene Fecal Microbiota Analysis. Microorganisms 2020, 8, 1151. [CrossRef] [PubMed]

77. Frese, S.A.; Parker, K.; Calvert, C.C.; Mills, D.A. Diet shapes the gut microbiome of pigs during nursing and weaning. Microbiome 2015, 3, 28. [CrossRef]

78. Lamendella, R.; Domingo, J.W.; Ghosh, S.; Martinson, J.; Oerther, D.B. Comparative fecal metagenomics unveils unique functional capacity of the swine gut. BMC Microbiol. 2011, 11, 103. [CrossRef]

79. Tan, Z.; Yang, T.; Wang, Y.; Xing, K.; Zhang, F.; Zhao, X.; Ao, H.; Chen, S.; Liu, J.; Wang, C. Metagenomic Analysis of Cecal Microbiome Identified Microbiota and Functional Capacities Associated with Feed Efficiency in Landrace Finishing Pigs. Front. Microbiol. 2017, 8, 1546. [CrossRef]

80. Flint, H.J.; Bayer, E.A. Plant cell wall breakdown by anaerobic microorganisms from the Mammalian digestive tract. Ann. N. Y. Acad. Sci. 2008, 1125, 280-288. [CrossRef]

81. Pollock, J.; Gally, D.L.; Glendinning, L.; Tiwari, R.; Hutchings, M.R.; Houdijk, J.G.M. Analysis of temporal fecal microbiota dynamics in weaner pigs with and without exposure to enterotoxigenic Escherichia coli1,2. J. Anim. Sci. 2018, 96, 3777-3790. [CrossRef] [PubMed]

82. Yang, Q.; Huang, X.; Zhao, S.; Sun, W.; Yan, Z.; Wang, P.; Li, S.; Huang, W.; Zhang, S.; Liu, L.; et al. Structure and Function of the Fecal Microbiota in Diarrheic Neonatal Piglets. Front. Microbiol. 2017, 8, 502. [CrossRef] [PubMed]

83. Kiros, T.G.; Luise, D.; Derakhshani, H.; Petri, R.; Trevisi, P.; D’Inca, R.; Auclair, E.; van Kessel, A.G. Effect of live yeast Saccharomyces cerevisiae supplementation on the performance and cecum microbial profile of suckling piglets. PLoS ONE 2019, 14, e0219557. [CrossRef] [PubMed]

84. Quan, J.; Cai, G.; Ye, J.; Yang, M.; Ding, R.; Wang, X.; Zheng, E.; Fu, D.; Li, S.; Zhou, S.; et al. A global comparison of the microbiome compositions of three gut locations in commercial pigs with extreme feed conversion ratios. Sci. Rep. 2018, 8, 4536. [CrossRef] 
85. Unno, T.; Choi, J.H.; Hur, H.G.; Sadowsky, M.J.; Ahn, Y.T.; Huh, C.S.; Kim, G.B.; Cha, C.J. Changes in human gut microbiota influenced by probiotic fermented milk ingestion. J. Dairy Sci. 2015, 98, 3568-3576. [CrossRef] [PubMed]

86. Sun, J.; Du, L.; Li, X.; Zhong, H.; Ding, Y.; Liu, Z.; Ge, L. Identification of the core bacteria in rectums of diarrheic and non-diarrheic piglets. Sci. Rep. 2019, 9, 18675. [CrossRef] [PubMed]

87. Koh, H.W.; Kim, M.S.; Lee, J.S.; Kim, H.; Park, S.J. Changes in the Swine Gut Microbiota in Response to Porcine Epidemic Diarrhea Infection. Microbes Environ. 2015, 30, 284-287. [CrossRef] [PubMed]

88. Yang, Q.; Huang, X.; Wang, P.; Yan, Z.; Sun, W.; Zhao, S.; Gun, S. Longitudinal development of the gut microbiota in healthy and diarrheic piglets induced by age-related dietary changes. Microbiologyopen 2019, 8, e923. [CrossRef]

89. Shirkey, T.W.; Siggers, R.H.; Goldade, B.G.; Marshall, J.K.; Drew, M.D.; Laarveld, B.; Van Kessel, A.G. Effects of commensal bacteria on intestinal morphology and expression of proinflammatory cytokines in the gnotobiotic pig. Exp. Biol. Med. 2006, 231, 1333-1345. [CrossRef]

90. Stokes, C.R. The development and role of microbial-host interactions in gut mucosal immune development. J. Anim. Sci. Biotechnol. 2017, 8, 12. [CrossRef]

91. Duncan, S.H.; Louis, P.; Flint, H.J. Lactate-utilizing bacteria, isolated from human feces, that produce butyrate as a major fermentation product. Appl. Environ. Microbiol. 2004, 70, 5810-5817. [CrossRef] [PubMed]

92. Ratajczak, W.; Rył, A.; Mizerski, A.; Walczakiewicz, K.; Sipak, O.; Laszczyńska, M. Immunomodulatory potential of gut microbiome-derived short-chain fatty acids (SCFAs). Acta Biochim. Pol. 2019, 66, 1-12. [CrossRef] [PubMed]

93. Franke, T.; Deppenmeier, U. Physiology and central carbon metabolism of the gut bacterium Prevotella copri. Mol. Microbiol. 2018, 109, 528-540. [CrossRef] [PubMed]

94. Cushing, K.; Alvarado, D.M.; Ciorba, M.A. Butyrate and Mucosal Inflammation: New Scientific Evidence Supports Clinical Observation. Clin. Transl. Gastroenterol. 2015, 6, e108. [CrossRef] [PubMed]

95. Zheng, L.; Kelly, C.J.; Battista, K.D.; Schaefer, R.; Lanis, J.M.; Alexeev, E.E.; Wang, R.X.; Onyiah, J.C.; Kominsky, D.J.; Colgan, S.P. Microbial-Derived Butyrate Promotes Epithelial Barrier Function through IL-10 Receptor-Dependent Repression of Claudin-2. J. Immunol. 2017, 199, 2976-2984. [CrossRef]

96. Pabst, O.; Slack, E. IgA and the intestinal microbiota: The importance of being specific. Mucosal Immunol. 2020, 13, 12-21. [CrossRef]

97. Donaldson, G.P.; Ladinsky, M.S.; Yu, K.B.; Sanders, J.G.; Yoo, B.B.; Chou, W.C.; Conner, M.E.; Earl, A.M.; Knight, R.; Bjorkman, P.J.; et al. Gut microbiota utilize immunoglobulin A for mucosal colonization. Science 2018, 360, 795-800. [CrossRef] [PubMed]

98. Xiao, Y.; Yan, H.; Diao, H.; Yu, B.; He, J.; Yu, J.; Zheng, P.; Mao, X.; Luo, Y.; Chen, D. Early Gut Microbiota Intervention Suppresses DSS-Induced Inflammatory Responses by Deactivating TLR/NLR Signalling in Pigs. Sci. Rep. 2017, 7, 3224. [CrossRef]

99. Lucke, K.; Miehlke, S.; Jacobs, E.; Schuppler, M. Prevalence of Bacteroides and Prevotella spp. in ulcerative colitis. J. Med. Microbiol. 2006, 55, 617-624. [CrossRef]

100. Maeda, Y.; Takeda, K. Host-microbiota interactions in rheumatoid arthritis. Exp. Mol. Med. 2019, 51, 1-6. [CrossRef]

101. Rodríguez-Piñeiro, A.M.; Johansson, M.E. The colonic mucus protection depends on the microbiota. Gut Microbes 2015, 6, 326-330. [CrossRef] [PubMed]

102. Rho, J.H.; Wright, D.P.; Christie, D.L.; Clinch, K.; Furneaux, R.H.; Roberton, A.M. A novel mechanism for desulfation of mucin: Identification and cloning of a mucin-desulfating glycosidase (sulfoglycosidase) from Prevotella strain RS2. J. Bacteriol. 2005, 187, 1543-1551. [CrossRef] [PubMed]

103. Rolhion, N.; Chassaing, B.; Nahori, M.A.; de Bodt, J.; Moura, A.; Lecuit, M.; Dussurget, O.; Bérard, M.; Marzorati, M.; Fehlner-Peach, H.; et al. A Listeria monocytogenes Bacteriocin Can Target the Commensal Prevotella copri and Modulate Intestinal Infection. Cell Host Microbe 2019, 26, 691-701. [CrossRef] [PubMed]

104. Ciabattini, A.; Olivieri, R.; Lazzeri, E.; Medaglini, D. Role of the Microbiota in the Modulation of Vaccine Immune Responses. Front. Microbiol. 2019, 10, 1305. [CrossRef] [PubMed]

105. Vlasova, A.N.; Takanashi, S.; Miyazaki, A.; Rajashekara, G.; Saif, L.J. How the gut microbiome regulates host immune responses to viral vaccines. Curr. Opin. Virol. 2019, 37, 16-25. [CrossRef]

106. Hagan, T.; Cortese, M.; Rouphael, N.; Boudreau, C.; Linde, C.; Maddur, M.S.; Das, J.; Wang, H.; Guthmiller, J.; Zheng, N.Y.; et al. Antibiotics-Driven Gut Microbiome Perturbation Alters Immunity to Vaccines in Humans. Cell 2019, 178, 1313-1328. [CrossRef] 
107. Lamousé-Smith, E.S.; Tzeng, A.; Starnbach, M.N. The intestinal flora is required to support antibody responses to systemic immunization in infant and germ free mice. PLoS ONE 2011, 6, e27662. [CrossRef]

108. Twitchell, E.L.; Tin, C.; Wen, K.; Zhang, H.; Becker-Dreps, S.; Azcarate-Peril, M.A.; Vilchez, S.; Li, G.; Ramesh, A.; Weiss, M.; et al. Modeling human enteric dysbiosis and rotavirus immunity in gnotobiotic pigs. Gut Pathog. 2016, 8, 51. [CrossRef]

109. Desselberger, U. The Mammalian Intestinal Microbiome: Composition, Interaction with the Immune System, Significance for Vaccine Efficacy, and Potential for Disease Therapy. Pathogens 2018, 7, 57. [CrossRef]

110. Munyaka, P.M.; Kommadath, A.; Fouhse, J.; Wilkinson, J.; Diether, N.; Stothard, P.; Estelle, J.; Rogel-Gaillard, C.; Plastow, G.; Willing, B.P. Characterization of whole blood transcriptome and early-life fecal microbiota in high and low responder pigs before, and after vaccination for Mycoplasma hyopneumoniae. Vaccine 2019, 37, 1743-1755. [CrossRef]

111. Chilton, P.M.; Hadel, D.M.; To, T.T.; Mitchell, T.C.; Darveau, R.P. Adjuvant activity of naturally occurring monophosphoryl lipopolysaccharide preparations from mucosa-associated bacteria. Infect. Immun. 2013, 81, 3317-3325. [CrossRef] [PubMed]

112. Takada, K.; Hirasawa, M.; Ikeda, T. Isolation and purification of bacteriocin from Prevotella intermedia (Bacteroides intermedius). J. Periodontol. 1991, 62, 439-444. [CrossRef] [PubMed]

113. Kaewsrichan, J.; Douglas, C.W.; Teanpaisan, R. Characterization of minimal bacteriocin operon from Prevotella nigrescens ATCC 25261. Lett. Appl. Microbiol. 2005, 40, 138-145. [CrossRef] [PubMed]

114. Dicks, L.M.T.; Dreyer, L.; Smith, C.; van Staden, A.D. Corrigendum: A Review: The Fate of Bacteriocins in the Human Gastro-Intestinal Tract: Do They Cross the Gut-Blood Barrier? Front. Microbiol. 2018, 9, 2938. [CrossRef] [PubMed]

115. Gould, A.L.; Zhang, V.; Lamberti, L.; Jones, E.W.; Obadia, B.; Korasidis, N.; Gavryushkin, A.; Carlson, J.M.; Beerenwinkel, N.; Ludington, W.B. Microbiome interactions shape host fitness. Proc. Natl. Acad. Sci. USA 2018, 115, E11951-E11960. [CrossRef] [PubMed]

116. Tett, A.; Huang, K.D.; Asnicar, F.; Fehlner-Peach, H.; Pasolli, E.; Karcher, N.; Armanini, F.; Manghi, P.; Bonham, K.; Zolfo, M.; et al. The Prevotella copri Complex Comprises Four Distinct Clades Underrepresented in Westernized Populations. Cell Host Microbe 2019, 26, 666-679. [CrossRef] [PubMed]

117. Clavel, T.; Gomes-Neto, J.C.; Lagkouvardos, I.; Ramer-Tait, A.E. Deciphering interactions between the gut microbiota and the immune system via microbial cultivation and minimal microbiomes. Immunol. Rev. 2017, 279, 8-22. [CrossRef]

118. Salipante, S.J.; SenGupta, D.J.; Cummings, L.A.; Land, T.A.; Hoogestraat, D.R.; Cookson, B.T. Application of whole-genome sequencing for bacterial strain typing in molecular epidemiology. J. Clin. Microbiol. 2015, 53, 1072-1079. [CrossRef]

119. Balloux, F.; Brønstad Brynildsrud, O.; van Dorp, L.; Shaw, L.P.; Chen, H.; Harris, K.A.; Wang, H.; Eldholm, V. From Theory to Practice: Translating Whole-Genome Sequencing (WGS) into the Clinic. Trends Microbiol. 2018, 26, 1035-1048. [CrossRef]

120. Johnson, J.S.; Spakowicz, D.J.; Hong, B.Y.; Petersen, L.M.; Demkowicz, P.; Chen, L.; Leopold, S.R.; Hanson, B.M.; Agresta, H.O.; Gerstein, M.; et al. Evaluation of 16S rRNA gene sequencing for species and strain-level microbiome analysis. Nat. Commun. 2019, 10, 5029. [CrossRef]

121. Ghimire, S.; Roy, C.; Wongkuna, S.; Antony, L.; Maji, A.; Keena, M.C.; Foley, A.; Scaria, J. Identification of Clostridioides difficile-Inhibiting Gut Commensals Using Culturomics, Phenotyping, and Combinatorial Community Assembly. mSystems 2020, 5. [CrossRef] [PubMed]

122. Fenske, G.J.; Ghimire, S.; Antony, L.; Christopher-Hennings, J.; Scaria, J. Integration of culture-dependent and independent methods provides a more coherent picture of the pig gut microbiome. FEMS Microbiol. Ecol. 2020, 96. [CrossRef] [PubMed]

123. Hayashi, H.; Shibata, K.; Sakamoto, M.; Tomita, S.; Benno, Y. Prevotella copri sp. nov. and Prevotella stercorea sp. nov., isolated from human faeces. Int. J. Syst. Evol. Microbiol. 2007, 57, 941-946. [CrossRef]

124. Varel, V.H.; Bryant, M.P. Nutritional features of Bacteroides fragilis subsp. fragilis. Appl. Microbiol. 1974, 28, 251-257. [CrossRef] [PubMed]

125. Zhang, X.; Li, L.; Butcher, J.; Stintzi, A.; Figeys, D. Advancing functional and translational microbiome research using meta-omics approaches. Microbiome 2019, 7, 154. [CrossRef] [PubMed] 
126. Chiquette, J.; Allison, M.J.; Rasmussen, M.A. Prevotella bryantii 25A used as a probiotic in early-lactation dairy cows: Effect on ruminal fermentation characteristics, milk production, and milk composition. J. Dairy Sci. 2008, 91, 3536-3543. [CrossRef] [PubMed]

127. Fraga, M.; Fernández, S.; Perelmuter, K.; Pomiés, N.; Cajarville, C.; Zunino, P. The use of Prevotella bryantii 3C5 for modulation of the ruminal environment in an ovine model. Braz J. Microbiol. 2018, 49 (Suppl. 1), 101-106. [CrossRef]

Publisher's Note: MDPI stays neutral with regard to jurisdictional claims in published maps and institutional affiliations.

(C) 2020 by the authors. Licensee MDPI, Basel, Switzerland. This article is an open access article distributed under the terms and conditions of the Creative Commons Attribution (CC BY) license (http://creativecommons.org/licenses/by/4.0/). 